\title{
MicroRNAs in biofluids are novel tools for bladder cancer screening
}

\author{
Xiaobing Liu ${ }^{1}$, Xin Liu ${ }^{1}$, Yuqi Wu ${ }^{1}$, Qingjian Wu ${ }^{1}$, Qingqing Wang ${ }^{1}$, Zhenxing Yang ${ }^{1}$ \\ and Longkun Li ${ }^{1}$ \\ ${ }^{1}$ Department of Urology, Second Affiliated Hospital, Third Military Medical University, Chongqing, China
}

Correspondence to: Longkun Li, email: lilongk@hotmail.com

Keywords: bladder cancer, microRNAs, biomarker, urine, blood

Received: January 12, $2017 \quad$ Accepted: February 17, $2017 \quad$ Published: March 08, 2017

Copyright: Liu et al. This is an open-access article distributed under the terms of the Creative Commons Attribution License (CC-BY), which permits unrestricted use, distribution, and reproduction in any medium, provided the original author and source are credited.

\section{ABSTRACT}

MicroRNAs (miRNAs) are short non-coding RNAs that play important roles in basic cellular processes, including differentiation, proliferation, apoptosis and autophagy. They are also involved in various stages of tumorigenesis and play key roles in bladder cancer initiation and progression. Notably, the altered expression of miRNAs in the tumors is reflected in body fluids, including blood and urine, which opens avenues for non-invasive diagnosis and prognosis. Many studies have demonstrated that epigenetic changes extensively alter tumoral microRNA expression. The high reproducibility, specificity and sensitivity of miRNA levels in body fluids suggest their potential use as biomarkers for cancer screening and diagnosis. For example, recent technological advances have made it possible to detect miRNAs in urine for bladder cancer screening. In this review, we focus mainly on the current knowledge and future challenges for incorporating miRNAs in body fluids, like urine and blood, for making clinical diagnoses and assessing prognoses in bladder cancer.

\section{INTRODUCTION}

Cancer is the leading cause of death and a major health problem worldwide including highly populated countries like China [1]. Bladder cancer is one of the 10 most common cancers in China that contributes to increasing morbidity and mortality. Though treatment methods such as surgery, radiotherapy, chemotherapy, and therapeutics have significantly improved the quality of life of bladder cancer patients [2], the prognosis and the 5 -year survival rate is extremely poor due to late diagnosis and aggressive metastasis [3]. Early diagnosis is key for positive prognosis and to improve the survival rate [4]. Therefore, newer and more powerful methods are required to detect bladder cancer in the early stages.

Cystoscopy is a traditional method to detect bladder cancer that has benefited many patients and remains a gold standard for bladder cancer diagnosis [4]. However, it is expensive, highly invasive and causes significant discomfort to patients [5]. In recent years, alternative biological screening methods such as the bladder tumor antigen (BTA stat test), nuclear matrix protein 22(NMP22) and urinary cytology have been used [6-8]. However, these alternate methods are either highly sensitive or specific and never both.

Recently, microRNAs (miRNAs) that are short, noncoding RNA sequences of 20-22 nucleotides have emerged as novel tumor biomarker candidates [9-12]. A number of studies have demonstrated the utility of miRNAs for early stage cancer detection [10-13]. MiRNAs are involved in various stages of tumorigenesis including tumor initiation, growth and progression [1416]. Further, miRNAs can function either as tumor suppressors (miR-15a and miR-16-1) or as oncogenes (miR-155 and members of the miR-17-92 cluster) [10]. The most promising aspect of miRNAs as molecular biomarkers is that they can be reproducibly extracted from a wide range of biological samples (such as blood plasma, urine, feces or biopsy specimen) and are generally stable and resistant to various storage conditions [17]. Also, highly sensitive and standardized techniques such as qRTPCR, small RNA sequencing, and microarray are already available to detect and quantify miRNAs.

The potential utility of miRNAs in the diagnosis, prognosis and treatment of bladder cancer has generated enormous interest [18]. In the past decade, the number 
of studies related to miRNAs in urologic cancer has increased [19], highlighting the importance of miRNAs in bladder cancer [20]. Therefore, in this article, we review the importance of body fluids as a source for miRNAs as biomarkers for early diagnosis of cancer. Then, we review the development and early clinical findings regarding detection of miRNAs in blood and urine for bladder cancer screening and discuss the potential areas of improvement necessary for clinical use. In addition, we review the current available methods for miRNA detection for cancer diagnosis.

\section{MICRORNAS IN BIOFLUIDS AS CANCER BIOMARKERS}

Fuentes-Arderiu X defined biomarker as "human or animal biological property whose in vitro measurement or identification is useful for the prevention, diagnosis, prognosis, treatment, and follow-up of human or animal diseases, and for their understanding" [21]. Many studies using The Cancer Genome Atlas (TCGA) data revealed that dysregulated miRNA expression profiles in cancer tissues was associated with tumor state, grade, size, aggressiveness and metastasis [22-24]. The current goal of precision medicine is to achieve personalized health care by classifying patients into distinct molecular groups accompanied with accurate prediction of disease risk to enable early intervention with the most suitable therapeutic approach to achieve better outcomes and avoid unnecessary treatment with adverse effects [25]. Therefore, miRNAs are good candidates as precision molecular markers for diagnosis, therapy choice and response surveillance.

MiRNAs are useful biomarkers because changes in miRNA in the tumors can be non-invasively detected in body fluids like blood and urine [26]. MiRNAs are secreted into body fluids by tumor cells via specific regulated pathways (Figure 1). The miRNAs can be detected in body fluids as either free circulating miRNAs or those that are bound to ribonucleoprotein complexes and encapsulated in extracellular vesicles [27-31]. The main protein binding partners of miRNAs are Argonaut proteins, high density lipoproteins (HDL) and nucleophosmins [27-29]. Also, miRNAs are secreted in extracellular vesicles such as exosomes, microvesicles or apoptotic bodies. Exosomes are multivesicular bodies that fuse with the plasma membrane; microvesicles are derived from outward budding of the cell membrane; and apoptotic bodies are formed during late stages of apoptosis via membrane blebbing that contain nuclear components and cytoplasm [31]. The miRNAs that are part of complex proteins and lipids or encapsulated in extracellular vesicles are protected from degradation and are stable in body fluids [32, 33]. The most extensively studied miRNAs are exosome-encapsulated miRNAs. It is observed that miRNA content in the secreting cells and the exosomes is different suggesting selective packaging of miRNAs into exosomes [32]. Further, enhanced exosome-encapsulated miRNAs is observed in metastatic cancer cells, which signifies their role in tumorigenesis [34]. Studies also indicate that miRNAs enable cell-cell communication, although the function and mechanism is still being investigated and is unclear [12].

MiRNAs can be easily screened and precisely quantified by a variety of standard methods like qRTPCR, insitu hybridization, enzymatic luminescence miRNA assay, microarray, or next-generation sequencing [35], which can be applied clinically to detect tumors at an early stage. The miRNAs are optimal biomarker candidates because they can be reproducibly isolated from a wide range of biological fluids and are generally stable and resistant to various storage conditions [17]. However, the development of a biomarker assay for the clinic is a multistage process and includes (1) identification of

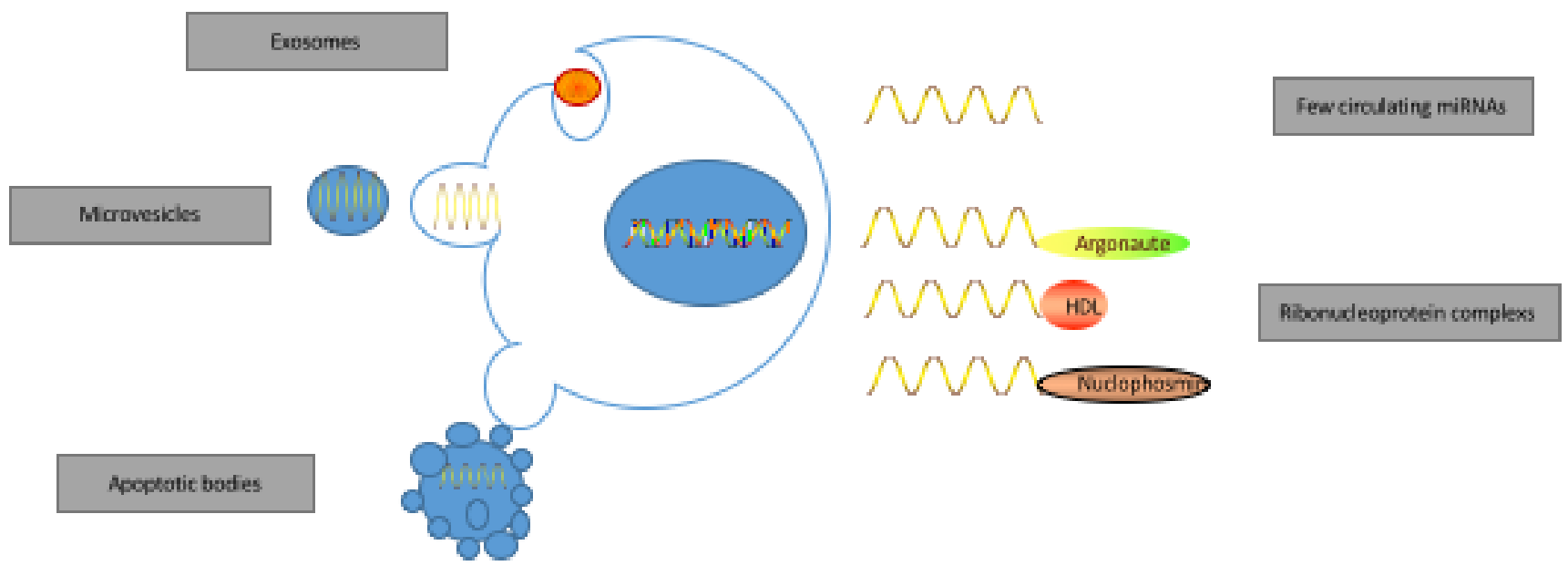

Figure 1: The origin of miRNAs in biofluids. 
Table 1: Studies regarding miRNAs in urine as potential biomarkers in bladder cancer

\begin{tabular}{|c|c|c|c|c|c|c|}
\hline Study & Year & Sample & Results & $\begin{array}{l}\text { BC/ } \\
\text { Cont(n }\end{array}$ & $\begin{array}{ll}\text { clinically } & \text { relevated } \\
\text { findings } & \\
\end{array}$ & Reference \\
\hline Hanke et al. & 2010 & Whole urine & Upregulate: miR-126,miR182 & $29 / / 11$ & $\begin{array}{l}\text { AUC }=0.768, \quad \mathrm{DS}=72 \%, \\
\mathrm{DSp}-83 \%\end{array}$ & 46 \\
\hline Yamada et al. & 2011 & Urine sediment & Upregulate: miR96, miR-183 & $100 / 74$ & $\begin{array}{l}\mathrm{AUC}=0.831 / 0.817 \\
\mathrm{DS}=71 / 74 \%, \mathrm{DSp}=79 / 77 \%\end{array}$ & 47 \\
\hline Miah et al. & 2012 & Urine sediment & $\begin{array}{l}\text { Upregulate: } \operatorname{miR}-15 b, \quad \operatorname{miR}-1224-3 p \text {; } \\
\text { downregulate: } \operatorname{miR}-135\end{array}$ & $68 / 53$ & $\begin{array}{l}\mathrm{AUC}=0.86, \quad \mathrm{DS}=94.1 \% \\
\mathrm{DSp}=51 \%\end{array}$ & 48 \\
\hline Puerta-Gil et a & 2012 & Urine (not defined) & $\begin{array}{l}\begin{array}{l}\text { Upregulate: } \quad \text { miR-222, } \\
\text { downregulate: }\end{array} \text { miR-143 } \\
\end{array}$ & $37 / 57$ & $\mathrm{AUC}=0.718, \mathrm{AUC}=0.848$ & 49 \\
\hline Snowdon et al & 2012 & Whole-urine & $\begin{array}{l}\text { Upregulate: miR-126; downregulate: miR- } \\
125 \text { b }\end{array}$ & $8 / 5$ & without data & 55 \\
\hline Wang et al. & 2012 & $\begin{array}{l}\text { Urine sediment and } \\
\text { superna }\end{array}$ & Upregulate: miR-141, miR200a/b/c, miR-429 & $51 / 24$ & $\begin{array}{l}\mathrm{AUC}=0.706-0.804 \\
\mathrm{DS}=100 \%, \mathrm{DSp}=53 \%\end{array}$ & 50 \\
\hline Yun et al. & 2012 & Urine supernatant & Upregulate: miR-145, miR-200a & $207 / 144$ & $\begin{array}{l}\begin{array}{l}\mathrm{AUC}=0.729 \text { and } \\
\mathrm{DS}=78 \% \text { and } \\
\mathrm{DSp}=61 \% \text { and } 61\end{array} \\
\end{array}$ & 51 \\
\hline Kim et al. & 2013 & Urine supernatant & Upregulate: miR-214 & $138 / 144$ & without data & 52 \\
\hline Mengual et al. & 2013 & Urine sediment & $\begin{array}{l}\text { Upregulate: miR-18a, miR-25, miR-187, } \\
\text { miR92a; downregulate: miR-140-5p, miR- } \\
\text { 142-3p, mi }\end{array}$ & $151 / 121$ & $\begin{array}{l}\mathrm{AUC}=0.92, \quad \mathrm{DS}-85 \% \\
\mathrm{DSp}=87 \%\end{array}$ & 53 \\
\hline Shimizu et al. & 2013 & Urine supernatant & Upregulate: miR-9-3, miR-142-2/3, miR-137 & $86 / 20$ & $\mathrm{AUC}=0.91$ & 54 \\
\hline Tolle et al. & 2013 & Whole urine & $\begin{array}{l}\text { Upregulate: miR-520e, miR-618, miR-122- } \\
5 \mathrm{p}\end{array}$ & $36 / 19$ & $\mathrm{AUC}=0.679-0.764$ & 56 \\
\hline Zhang et al. & 2014 & Urine supernatant & Upregulate: miR-99a, miR-125b & $50 / 21$ & $\begin{array}{l}\mathrm{AUC}=0.876, \quad \mathrm{DS}=79 \% \\
\mathrm{DSp}=88 \%\end{array}$ & 57 \\
\hline Zhou et al. & 2014 & Urine supernatant & Upregulate: miR-106b & $112 / 78$ & $\begin{array}{l}\mathrm{AUC}=0.802, \quad \mathrm{DS}=76.8 \% \\
\mathrm{DSp}=72.4 \%\end{array}$ & 58 \\
\hline Eissa et al. & 2015 & Urine sediment & Upregulate: miR-96 & $94 / 90$ & $\begin{array}{l}\mathrm{AUC}=0.822, \quad \mathrm{DS}=76.8 \% \\
\mathrm{DSp}=88.9 \%\end{array}$ & 59 \\
\hline Eissa et al. & 2015 & Urine sediment & Upregulate: miR-210, miR-96 & $94 / 56$ & $\begin{array}{l}\mathrm{AUC}=0.933, \quad \mathrm{DS}=100 \% \\
\mathrm{DSp}=89.5 \%\end{array}$ & 60 \\
\hline Liu et al. & 2015 & Urine sediment & Upregulate: miR-141, miR-200b & $78 / 54$ & $\mathrm{AUC}=0.749$ & 61 \\
\hline Long et al. & 2015 & Urine supernatant & $\begin{array}{l}\text { Upregulate: let-7b, miR-15a, miR-21, miR- } \\
\text { 26a, miR-93, miR-101, miR-200c, miR-940 }\end{array}$ & $85 / 45$ & $\begin{array}{l}\mathrm{AUC}=0.858, \quad \mathrm{DS}=70 \%, \\
\mathrm{DSp}=84 \%\end{array}$ & 62 \\
\hline Wang et al. & 2015 & Urine supernatant & Upregulate: miR-214, & $292 / 169$ & $\begin{array}{l}\mathrm{AUC}=0.838, \quad \mathrm{DS}=90.5 \% \\
\mathrm{DSp}=65.6 \%\end{array}$ & 63 \\
\hline Spare et al. & 2016 & Whole urine & $\begin{array}{l}\text { Upregulate: } \mathrm{miR}-16, \mathrm{miR}-21 \text {, miR-34a, miR- } \\
\text { 200c, miR-205, miR-211 }\end{array}$ & $60 / 21$ & $\begin{array}{l}\mathrm{AUC}=0.74 \\
\mathrm{DSp}=48 \%\end{array}$ & 64 \\
\hline Urquidi et al. & 2016 & Uriene(not defined) & 25-miRNA model & $88 / 118$ & $\mathrm{AUC}=0.982$ & 66 \\
\hline
\end{tabular}

potential markers in discovery phase; (2) development of specificity and sensitivity assays, and (3) extensive validation steps. Currently, there are many methodological pitfalls that need to be addressed in order for miRNAs from biofluids to be used for clinical applications. These include improving and standardizing methods of sample collection, storage, RNA isolation, sequencing and data evaluation [36-40]. In spite of these challenges that require rigorous studies, miRNAs in body fluids have enormous potential as novel diagnostic and prognostic markers for cancer screening.

\section{MICRORNA IN BODY FLUIDS AND BLADDER CANCER}

In most cases, bladder cancer has metastasized at diagnosis [41]. Bladder cancer is classified into two different types based on the pathology, namely, nonmuscle invasive bladder cancer (NMIBC) that is confined to the mucosa or submucosa, and muscle invasive bladder cancer (MBIC) that has invaded the muscle. The European Association of Urology (EAU) guidelines on NMBIC define three main purposes in applying new molecular biomarkers: (1) screening of the population at risk of developing bladder cancer; (2) evaluation of patients with symptoms suspicious for bladder cancer; and (3) facilitate surveillance of patients with bladder cancer to reduce the number of cystoscopies undertaken [42]. Therefore, in addition to the diagnosis of cancer, the surveillance of recurrence and progression from NMIBC to MIBC are critical. In regard to MIBC, different therapeutic options can alter progression and metastasis that are evaluated by disease free survival (DFS), cancer specific survival and overall survival (OS). Also, both NMIBC and MIBC have different molecular characteristics [43]. There are several methods to diagnose bladder cancer. Since the standard diagnostic tool, cystoscopy, has low diagnostic sensitivity in detecting low-grade bladder cancer in addition to being 
Table 2: Studies regarding miRNAs in blood as potential biomarkers in bladder cancer

\begin{tabular}{|c|c|c|c|c|c|c|}
\hline Study & Year & Sample & Results & BC/Cont(n & clinically relevated findings & Referenc \\
\hline Tolle et al. & 2013 & Whole-bloo & $\begin{array}{l}\text { Upregulate: miR-26a-5p, mir-144-5p, miR-374- } \\
5 \mathrm{p}\end{array}$ & $38 / 20$ & $\mathrm{AUC}=0.774-0.824$ & 56 \\
\hline Adam et al. & 2013 & Plasma & No different & $20 / 18$ & no difference & 75 \\
\hline Scheffer et $a$ & 2014 & Serum & miR-141,miR-639 & $126 / 105$ & No different levels between study gr & 73 \\
\hline Feng et al. & 2014 & Plasma & Upregulate: miR-99a & $50 / 50$ & without data & 80 \\
\hline Feng et al. & 2014 & Plasma & Upregulate: miR-19a & $50 / 50$ & without data & 76 \\
\hline Jiang et al. & 2015 & Serum & $\begin{array}{l}\text { Upregulate: miR-152; downregulate: miR-1486- } \\
\text { 3p, miR-3187-3p, miR-15b-5p, miR-27a- }\end{array}$ & $120 / 120$ & AUC $=0.899, \mathrm{DS}=80 \%, \mathrm{DSp}=89 \%$ & 68 \\
\hline Kreebel et al. & 2015 & Serum & Upregulate: miR-1141 & $34 / 34$ & $\mathrm{AUC}=0.726, \mathrm{DS}=70.5 \%, \mathrm{DSp}=73.5$ & 74 \\
\hline Du et al. & 2015 & Plasma & Upregulate: miR-663b; downregulate: miR-497 & $165 / 175$ & AUC $=0.711, \mathrm{DS}=69.7 \%, \mathrm{DSp}=69.6$ & 69 \\
\hline Yang et al. & 2015 & Serum & Upregulate: miR-210 & $168 / 104$ & without data & 79 \\
\hline Tao et al. & 2015 & serum & 13-miRNA model & $46 / 30$ & AUC $>0.8$ & 81 \\
\hline Motawi et al. & 2016 & Plasma & downregulate: miR-92a, miR-100, miR-143 & $70 / 62$ & AUC $=0.926$ & 78 \\
\hline
\end{tabular}

inconvenient and costly for patients, numerous noninvasive urine based tests BTA stat test, nuclear matrix protein 22(NMP22) and urinary cytology have been used [6-8]. However, these alternate methods are either highly sensitive or specific and never both. However, the dysregulation of miRNAs in bladder cancer tissue is also manifest in urine and blood demonstrating their advantage as new biomarkers for bladder cancer [44]. Therefore, different miRNA patterns in the body fluids may reflect the progressive nature of the bladder cancer that could potentially be used for diagnostic and prognostic purposes in the clinic [45].

\section{MICRORNAS IN URINE SAMPLES}

In 2010, Hanke et al first reported miRNAs in urine samples as a diagnosis tool for bladder cancer [46]. Since then, a number of single-center, case-control studies have reported in this area [46-66]. Only one study has focused on miRNAs for surveillance in bladder cancer which using a panel of 12 miRNAs shows promise for detection of tumor recurrence in the surveillance of bladder cancer [64]. And multi-center, prospective cohort studies have not been reported so far. Yet, miRNAs in biological fluids for bladder cancer hold enormous promise as biomarkers due to their high specificity and sensitivity $[47,49,50,67]$ (Table 1). Increasing studies have reported on the potential of miRNAs as prognostic markers, although specific miRNAs have not yet been authenticated [52, 63, 64]. Further, studies have implied that combination of miRNAs enhance the specificity and sensitivity of diagnostic assays than single miRNAs alone $[53,54,64,68]$.

I order to translate the potential indicated by the preliminary studies, potential biomarker miRNAs need to be validated using large patient cohorts and multicenter studies. The current data is not amenable for validation because of multiple varying factors such as different objectives of each study, the heterogeneity of study cohorts and variation in the source and preparation of urine test materials (whole urine, sediment urine, urine supernatant, and urine exosome). Also, lack of standard protocol in processing the samples inspite of commercially available kits (Norgen, Exiqon, Qiagen) is a problem [57]. Further, there is great variation in the miRNAs or miRNA combinations that are focused in each study due to investigator's interest or the available tumor samples. Such a methodology is not optimal to standardize miRNA biomarkers in urine for bladder cancer screening. Another important factor that needs to be considered for clinical purposes is that miRNAs released from cultured cells are the basis of most investigations and may not be representative of those found in the biological fluids or primary tumors. Therefore, comprehensive and standardized methods of biomarker detection are necessary that need to be applied to such studies worldwide. The most widely accepted protocol is preliminary investigation based on genome-wide discovery methods followed by sequencing or microarray investigations and analysis, and subsequent validation of candidate miRNAs by qRT-PCR [62, 68, 69]. Importantly, only two studies (Sapre et al [64] and Eissa et al [60]) followed the EAU guidelines while evaluating the diagnostic specificity and sensitivity of the miRNAs that mandates direct comparison of the performance of candidate miRNAs with the gold standard of cytology or other urine tests. Eissa et al screened bladder cancer patients with negative cytoscopy results by combining cytology results with expression of miR96 and miR-210 and achieved an AUC value of 0.933 [60]. Sapre et al used the integrative approach with a panel of 12 miRNAs that reduced cystoscopy rate by $30 \%$ through enhancing diagnostic sensitivity and specificity to $88 \%$ and $48 \%$, respectively [64]. Currently, further study is necessary in this area as according to Standards for Reporting Diagnostic Accuracy (STARD) guidelines, 
Table 3: Characteristics of common methods used in miRNA diagnosis

\begin{tabular}{|l|l|l|l|}
\hline Methods & Advantage & Limitation & Reforence \\
\hline RT-RCR & Easy to operate and high sensi & Low thoughput, Expen & $91-93$ \\
\hline Microarray & High throughput & Lack of quantitative dat & $99-102$ \\
\hline Nortern blot analysis & Gold standard, High specificity & Poor sensitivity & $86-89$ \\
\hline Bioluminescence & High sensitivity & Complex steps & 90 \\
\hline In situ hybridization & High speicificity & Low thoughput, Expen & $95-98$ \\
\hline Fluorescence correlation spectro & High sensitivity & Special equipment & 94 \\
\hline
\end{tabular}

the new method needs to be compared with the gold standard and the data published [70]. In addition to these issues, several studies have associated miRNAs with hemolysis [71, 72]. Since hematuria is a critical symptom of bladder cancer [42], miRNAs are released from the erythrocytes and these must be excluded during bladder cancer screening. Therefore, it is also important to identify miRNAs that are bonafide and cancer-specific versus those that are due to hematuria.

\section{MICRORNAS IN SERUM AND PLASMA SAMPLES}

Table 2 shows the studies reporting miRNA in blood samples suggesting a similar trend to urine $[56,68,69$, 73-81]. Although deregulated miRNAs were previously reported in bladder cancer tissues, the first report on miRNA screening in blood samples was reported in 2013 by Adam et al [75]. In 2015, Du et al [68] and Jaing et al [69] used genome-wide, array-based profiling of large samples and validation cohorts that critically analyzed the diagnostic and prognostic potential of circulating miRNAs. Du et al used two-phase validation method and showed that two miRNAs from a list of eight miRNAs previously identified in the discovery phase,namely, miR497 and miR-663b demonstrated enhanced sensitivity and specificity with an AUC value of 0.711 [69]. Jiang et al used a similar method to achieve an AUC value of 0.899 for a panel of six miRNAs that differentiate patients with NMIBC and MIBC [68]. In both studies, the miRNA combinations demonstrated the potential to predict tumor recurrence.

Based on the preliminary studies discussed above, miRNAs in urine and blood can be potential biomarkers for bladder cancer and need to be investigated further. Therefore, well-designed, multi-center, prospective studies with optimal isolation conditions, data analysis, study design and miRNA panels are of critical importance to evaluate clinical screening of miRNAs in urine and blood for bladder cancer.

\section{COMMON METHODS FOR MICRORNA DETECTION}

The challenges in detecting miRNAs in body fluids for clinical evaluations include reproducibility and methodological pitfalls. The critical factors that affect optimal miRNA measurements include sample collection methods, processing and storage conditions, RNA isolation technique, quality control, quantification principle and data evaluation methods. Sample collection is a very important step that influences the stability of the final results. Currently, there are no standardized conditions described for this step. It is important that criteria like age, ethnic group, gender and prior treatment be considered [82]. The three generally used miRNA isolation methods are miRNeasy kit, TRIzol and mirVANA [83], which have slight differences that may be a source of bias. Therefore, researchers should choose appropriate technology to detect miRNAs in body fluids that would ensure stability and reproducibility [82]. In most cases, Students t-test is used to analyze the statistical significance of the differences in samples to determine their clinical relevance [84].

For quantitative and qualitative evaluation of miRNAs, various methods like Northern blotting, microarray technology, luminescence-based assays, electrochemical assays and in situ hybridization [85]. In most cases, the assays are based on Watson-Crick basepairing between complementary chains of nucleotides and require hybridization between the nuclei acid probe and target miRNA. The miRNA expression can vary based on the detection methods such as microarray and qRT-PCR. For clinical applications, acquisition of highly reproducible data is necessary to produce a reliable profile. Table 3 compares the application, advantages, disadvantages and improvements of various detection methods including Northern blot analysis, bioluminescence, qRT-PCR, fluorescence correlation spectroscopy, in situ hybridization and microarray [86-102].

For clinical applications, laboratory scientists, bioinformaticians, clinicians and statisticians need to ensure reliable and reproducible data. Thus, standardizing highly reliable protocols to obtain miRNA samples and highly sensitive methods to accurately and reproducibly 
evaluate the miRNAs is critical for establishing them as biomarkers.

\section{FUTURE PERSPECTIVES}

Currently, studies indicate that non-invasive detection of circulating miRNAs from body fluids of bladder cancer patients reflect the dysregulation in bladder cancer patients at different cancer stages. Increasing studies have investigated circulating miRNAs in bladder cancer in the past five years and nextgeneration sequencing has become more affordable and faster enabling rapid sequencing of biofluids in largescale, multicenter studies. Notably, a number of studies indicated that the miRNAs changes in tissue are not always consistent in blood and urine, highlighting that secretion pathway exists from tissue to biofluids [19, 77]. However, systematic multicenter and prospective cohort studies evaluating specific miRNAs that have been studied in tissue samples is missing in the biofluids. The currently available data is unreliable due to differences in methodology in various studies and heterogeneity of tested biofluids. Furthermore, in the absence of complementary studies, potentially important miRNAs may still be undiscovered and currently the clinical application based on available data is limited. Further, since the miRNA secretion pathway influences the stability of miRNAs in the biofluids, exosomal miRNA and miRNA bound in ribonucleoprotein complexes are stable and most suitable for the sensitive and robust marker detection, whereas free circulating miRNAs and miRNAs bound to proteins or packaged in vesicles are unsuitable due to their limited stability.

Currently, there is no standard consensus regarding methods for biofluids preparation and miRNA sequencing. In general multiple sources of blood (plasma, serum and whole blood) and urine (supernatant, sediment and whole urine) are randomly used for miRNA isolation. Further, factors such as hematuria and hemolysis that influence the reliability of the outcomes need to be considered to mitigate the bias. Next generation sequencing and digital PCR are more accurate and sensitive and need to be considered than the conventional methods such as microarrays and qRT-PCR that have inherent weaknesses and inconsistencies [103].

Further, multicenter, prospective cohort studies with stringent test conditions are necessary to validate circulating miRNAs. Also, other specific clinical needs such as surveillance markers need to be addressed to reduce the need of the invasive cystoscopy for bladder cancer patients. From the statistical standpoint, further studies that incorporate evaluation using multivariate models to evaluate miRNA combinations is necessary. If all these aspects are considered and rigorously evaluated, miRNAs and miRNA combinations hold enormous promise as diagnostic, prognostic, and predictive markers.

\section{CONCLUSIONS}

To conclude, circulating miRNAs in biofluids are promising markers for potential non-invasive bladder cancer screening. Among the various challenges ahead, overcoming the methodological bias by highly standardized and sensitive technologies and rigorous multiple center, prospective cohort studies are necessary to identify and establish circulating miRNAs as biomarkers for bladder cancer for clinical applications in the near future.

\section{ACKNOWLEDGMENTS}

This work was supported by the National Natural Science Foundation of China (Nos. 81170705 and 81230017).

\section{CONFLICTS OF INTERESTS}

The authors declare no conflict of interests.

\section{REFERENCES}

1. Chen W, Zheng R, Baade PD, Zhang S, Zeng H, Bray F, Jemal A, Yu XQ, He J. Cancer statistics in China, 2015. CA Cancer J Clin. 2016; 66:115-132.

2. Atkins CD, Wrzesinski SH. Radiotherapy plus chemotherapy in muscle-invasive bladder cancer. N Engl J Med. 2012; 367:380-381.

3. James ND, Hussain SA, Hall E, Jenkins P, Tremlett J, Rawlings C, Crundwell M, Sizer B, Sreenivasan T, Hendron C, Lewis R, Waters R, Huddart RA. Radiotherapy with or without chemotherapy in muscle-invasive bladder cancer. $\mathrm{N}$ Engl J Med. 2012; 366:1477-1488.

4. Blick CG, Nazir SA, Mallett S, Turney BW, Onwu NN, Roberts IS, Crew JP, Cowan NC. Evaluation of diagnostic strategies for bladder cancer using computed tomography (CT) urography, flexible cystoscopy and voided urine cytology: results for 778 patients from a hospital haematuria clinic. BJU Int. 2012; 110:84-94.

5. van Rhijn BW, van der Poel HG, van der Kwast TH. Urine markers for bladder cancer surveillance: a systematic review. Eur Urol. 2005; 47:736-748.

6. Simon MA, Lokeshwar VB, Soloway MS. Current bladder cancer tests: unnecessary or beneficial? Critical reviews in oncology/hematology. 2003; 47:91-107.

7. Bassi P, De Marco V, De Lisa A, Mancini M, Pinto F, Bertoloni R, Longo F. Non-invasive diagnostic tests for bladder cancer: a review of the literature. Urologia internationalis. 2005; 75:193-200.

8. Xylinas E, Kluth LA, Rieken M, Karakiewicz PI, Lotan Y, Shariat SF. Urine markers for detection and surveillance of bladder cancer. Urologic oncology. 2014; 32:222-229. 
9. Chen M, Calin GA, Meng QH. Circulating microRNAs as Promising Tumor Biomarkers. Advances in clinical chemistry. 2014; 67:189-214.

10. Fabris L, Ceder Y, Chinnaiyan AM, Jenster GW, Sorensen KD, Tomlins S, Visakorpi T, Calin GA. The Potential of MicroRNAs as Prostate Cancer Biomarkers. Eur Urol. 2016; 70:312-322.

11. Fedorko M, Pacik D, Wasserbauer R, Juracek J, Varga G, Ghazal M, Nussir MI. MicroRNAs in the pathogenesis of renal cell carcinoma and their diagnostic and prognostic utility as cancer biomarkers. The International journal of biological markers. 2016; 31:e26-37.

12. Junker K, Heinzelmann J, Beckham C, Ochiya T, Jenster G. Extracellular Vesicles and Their Role in Urologic Malignancies. Eur Urol. 2016; 70:323-331.

13. Xiao S, Wang J, Xiao N. MicroRNAs as noninvasive biomarkers in bladder cancer detection: a diagnostic metaanalysis based on qRT-PCR data. The International journal of biological markers. 2016; 31:e276-285.

14. Calin GA, Croce CM. MicroRNA signatures in human cancers. Nature reviews Cancer. 2006; 6:857-866.

15. Plaisance-Bonstaff K, Renne R. Viral miRNAs. Methods in molecular biology (Clifton, NJ). 2011; 721:43-66.

16. Harfe BD. MicroRNAs in vertebrate development. Current opinion in genetics \& development. 2005; 15:410-415.

17. Chen X, Ba Y, Ma L, Cai X, Yin Y, Wang K, Guo J, Zhang Y, Chen J, Guo X, Li Q, Li X, Wang W, et al. Characterization of microRNAs in serum: a novel class of biomarkers for diagnosis of cancer and other diseases. Cell research. 2008; 18:997-1006.

18. Schaefer A, Stephan C, Busch J, Yousef GM, Jung K. Diagnostic, prognostic and therapeutic implications of microRNAs in urologic tumors. Nat Rev Urol. 2010; 7:286297.

19. Fendler A, Stephan C, Yousef GM, Kristiansen G and Jung $\mathrm{K}$. The translational potential of microRNAs as biofluid markers of urological tumours. Nat Rev Urol. 2016; 13:734752.

20. Zheng LF, Sun WY. Meta-analysis of microRNAs as biomarkers for muscle-invasive bladder cancer. Biomedical reports. 2016; 5:159-164.

21. Fuentes-Arderiu X. What is a biomarker? It's time for a renewed definition. Clinical chemistry and laboratory medicine. 2013; 51:1689-1690.

22. Weinstein JN, Akbani R, Broom BM, Wang W, Verhaak RG, McConkey D, Lerner S, Morgan M, Creighton CJ, Smith C, Kwiatkowski DJ, Cherniack AD, Kim J, Sekhar Pedamallu C, et al. Comprehensive molecular characterization of urothelial bladder carcinoma. Nature. 2014; 507:315-322.

23. Abeshouse A, Ahn J, Akbani R, Ally A, Amin S, Andry CD, Annala M, Aprikian A, Armenia J, Arora A, Auman JT, Balasundaram M, Balu S, Barbieri CE, et al. The Molecular Taxonomy of Primary Prostate Cancer. Cell.
2015; 163:1011-1025.

24. Linehan WM, Spellman PT, Ricketts CJ, Creighton CJ, Fei SS, Davis C, Wheeler DA, Murray BA, Schmidt L, Vocke CD, Peto M, Al Mamun AA, Shinbrot E, et al. Comprehensive Molecular Characterization of Papillary Renal-Cell Carcinoma. N Engl J Med. 2016; 374:135-145.

25. Ibrahim R, Pasic M, Yousef GM. Omics for personalized medicine: defining the current we swim in. Expert review of molecular diagnostics. 2016; 16:719-722.

26. Weber JA, Baxter DH, Zhang S, Huang DY, Huang KH, Lee MJ, Galas DJ, Wang K. The microRNA spectrum in 12 body fluids. Clinical chemistry. 2010; 56:1733-1741.

27. Arroyo JD, Chevillet JR, Kroh EM, Ruf IK, Pritchard CC, Gibson DF, Mitchell PS, Bennett CF, PogosovaAgadjanyan EL, Stirewalt DL, Tait JF, Tewari M. Argonaute2 complexes carry a population of circulating microRNAs independent of vesicles in human plasma. Proc Natl Acad Sci U S A. 2011; 108:5003-5008.

28. Vickers KC, Palmisano BT, Shoucri BM, Shamburek RD, Remaley AT. MicroRNAs are transported in plasma and delivered to recipient cells by high-density lipoproteins. Nat Cell Biol. 2011; 13:423-433.

29. Wang K, Zhang S, Weber J, Baxter D, Galas DJ. Export of microRNAs and microRNA-protective protein by mammalian cells. Nucleic Acids Res. 2010; 38:7248-7259.

30. Franzen CA, Blackwell RH, Foreman KE, Kuo PC, Flanigan RC and Gupta GN. Urinary Exosomes: The Potential for Biomarker Utility, Intercellular Signaling and Therapeutics in Urological Malignancy. J Urol. 2016; 195:1331-1339.

31. Iftikhar H, Carney GE. Evidence and potential in vivo functions for biofluid miRNAs: From expression profiling to functional testing: Potential roles of extracellular miRNAs as indicators of physiological change and as agents of intercellular information exchange. BioEssays : news and reviews in molecular, cellular and developmental biology. 2016; 38:367-378.

32. Mitchell PS, Parkin RK, Kroh EM, Fritz BR, Wyman SK, Pogosova-Agadjanyan EL, Peterson A, Noteboom J, O'Briant KC, Allen A, Lin DW, Urban N, Drescher CW, et al. Circulating microRNAs as stable blood-based markers for cancer detection. Proc Natl Acad Sci U S A. 2008; 105:10513-10518.

33. Mall C, Rocke DM, Durbin-Johnson B, Weiss RH. Stability of miRNA in human urine supports its biomarker potential. Biomarkers in medicine. 2013; 7:623-631.

34. Ostenfeld MS, Jeppesen DK, Laurberg JR, Boysen AT, Bramsen JB, Primdal-Bengtson B, Hendrix A, Lamy P, Dagnaes-Hansen F, Rasmussen MH, Bui KH, Fristrup $\mathrm{N}$, Christensen EI, et al. Cellular disposal of miR23b by RAB27-dependent exosome release is linked to acquisition of metastatic properties. Cancer Res. 2014; 74:5758-5771.

35. Lan H, Lu H, Wang X, Jin H. MicroRNAs as potential biomarkers in cancer: opportunities and challenges. BioMed 
research international. 2015; 2015:125094.

36. McDonald JS, Milosevic D, Reddi HV, Grebe SK, Algeciras-Schimnich A. Analysis of circulating microRNA: preanalytical and analytical challenges. Clinical chemistry. $2011 ; 57: 833-840$.

37. Kirschner MB, van Zandwijk N, Reid G. Cell-free microRNAs: potential biomarkers in need of standardized reporting. Frontiers in genetics. 2013; 4:56.

38. Farina NH, Wood ME, Perrapato SD, Francklyn CS, Stein GS, Stein JL, Lian JB. Standardizing analysis of circulating microRNA: clinical and biological relevance. Journal of cellular biochemistry. 2014; 115:805-811.

39. Mlcochova H, Hezova R, Stanik M, Slaby O. Urine microRNAs as potential noninvasive biomarkers in urologic cancers. Urologic oncology. 2014; 32:41.e41-49.

40. Ralla B, Stephan C, Meller S, Dietrich D, Kristiansen G, Jung K. Nucleic acid-based biomarkers in body fluids of patients with urologic malignancies. Critical reviews in clinical laboratory sciences. 2014; 51:200-231.

41. Jemal A, Siegel R, Ward E, Hao Y, Xu J, Thun MJ. Cancer statistics, 2009. CA Cancer J Clin. 2009; 59:225-249.

42. Babjuk M, Oosterlinck W, Sylvester R, Kaasinen E, Bohle A, Palou-Redorta J, Roupret M. EAU guidelines on nonmuscle-invasive urothelial carcinoma of the bladder, the 2011 update. Eur Urol. 2011; 59:997-1008.

43. Knowles MA, Hurst CD. Molecular biology of bladder cancer: new insights into pathogenesis and clinical diversity. Nature reviews Cancer. 2015; 15:25-41.

44. Netto GJ. Molecular biomarkers in urothelial carcinoma of the bladder: are we there yet? Nat Rev Urol. 2011; 9:41-51.

45. Rosenberg E, Baniel J, Spector Y, Faerman A, Meiri E, Aharonov R, Margel D, Goren Y, Nativ O. Predicting progression of bladder urothelial carcinoma using microRNA expression. BJU Int. 2013; 112:1027-1034.

46. Hanke M, Hoefig K, Merz H, Feller AC, Kausch I, Jocham D, Warnecke JM, Sczakiel G. A robust methodology to study urine microRNA as tumor marker: microRNA-126 and microRNA-182 are related to urinary bladder cancer. Urologic oncology. 2010; 28:655-661.

47. Yamada Y, Enokida H, Kojima S, Kawakami K, Chiyomaru T, Tatarano S, Yoshino H, Kawahara K, Nishiyama K, Seki N, Nakagawa M. MiR-96 and miR-183 detection in urine serve as potential tumor markers of urothelial carcinoma: correlation with stage and grade, and comparison with urinary cytology. Cancer science. 2011; 102:522-529.

48. Miah S, Dudziec E, Drayton RM, Zlotta AR, Morgan SL, Rosario DJ, Hamdy FC, Catto JW. An evaluation of urinary microRNA reveals a high sensitivity for bladder cancer. $\mathrm{Br}$ J Cancer. 2012; 107:123-128.

49. Puerta-Gil P, Garcia-Baquero R, Jia AY, Ocana S, AlvarezMugica M, Alvarez-Ossorio JL, Cordon-Cardo C, Cava F, Sanchez-Carbayo M. miR-143, miR-222, and miR-452 are useful as tumor stratification and noninvasive diagnostic biomarkers for bladder cancer. The American journal of pathology. 2012; 180:1808-1815.

50. Wang G, Chan ES, Kwan BC, Li PK, Yip SK, Szeto CC, $\mathrm{Ng}$ CF. Expression of microRNAs in the urine of patients with bladder cancer. Clinical genitourinary cancer. 2012; 10:106-113.

51. Yun SJ, Jeong P, Kim WT, Kim TH, Lee YS, Song PH, Choi YH, Kim IY, Moon SK, Kim WJ. Cell-free microRNAs in urine as diagnostic and prognostic biomarkers of bladder cancer. International journal of oncology. 2012; 41:18711878.

52. Kim SM, Kang HW, Kim WT, Kim YJ, Yun SJ, Lee SC, Kim WJ. Cell-Free microRNA-214 From Urine as a Biomarker for Non-Muscle-Invasive Bladder Cancer. Korean journal of urology. 2013; 54:791-796.

53. Mengual L, Lozano JJ, Ingelmo-Torres $\mathrm{M}$, Gazquez $\mathrm{C}$, Ribal MJ, Alcaraz A. Using microRNA profiling in urine samples to develop a non-invasive test for bladder cancer. Int J Cancer. 2013; 133:2631-2641.

54. Shimizu T, Suzuki H, Nojima M, Kitamura H, Yamamoto E, Maruyama R, Ashida M, Hatahira T, Kai M, Masumori $\mathrm{N}$, Tokino $\mathrm{T}$, Imai $\mathrm{K}$, Tsukamoto $\mathrm{T}$, et al. Methylation of a panel of microRNA genes is a novel biomarker for detection of bladder cancer. Eur Urol. 2013; 63:1091-1100.

55. Snowdon J, Boag S, Feilotter H, Izard J and Siemens DR. A pilot study of urinary microRNA as a biomarker for urothelial cancer. Canadian Urological Association journal. 2013; 7:28-32.

56. Tolle A, Jung M, Rabenhorst S, Kilic E, Jung K, Weikert S. Identification of microRNAs in blood and urine as tumour markers for the detection of urinary bladder cancer. Oncol Rep. 2013; 30:1949-1956.

57. Zhang DZ, Lau KM, Chan ES, Wang G, Szeto CC, Wong $\mathrm{K}$, Choy RK, Ng CF. Cell-free urinary microRNA-99a and microRNA-125b are diagnostic markers for the noninvasive screening of bladder cancer. PLoS One. 2014; 9:e100793.

58. Zhou X, Zhang X, Yang Y, Li Z, Du L, Dong Z, Qu A, Jiang $\mathrm{X}$, Li P, Wang C. Urinary cell-free microRNA$106 \mathrm{~b}$ as a novel biomarker for detection of bladder cancer. Medical oncology (Northwood, London, England). 2014; 31:197.

59. Eissa S, Habib H, Ali E, Kotb Y. Evaluation of urinary miRNA-96 as a potential biomarker for bladder cancer diagnosis. Medical oncology (Northwood, London, England). 2015; 32:413.

60. Eissa S, Matboli M, Essawy NO, Kotb YM. Integrative functional genetic-epigenetic approach for selecting genes as urine biomarkers for bladder cancer diagnosis. Tumour Biol. 2015; 36:9545-9552.

61. Liu W, Qi L, Lv H, Zu X, Chen M, Wang J, Liu L, Zeng F, Li Y. MiRNA-141 and miRNA-200b are closely related to invasive ability and considered as decision-making biomarkers for the extent of PLND during cystectomy. BMC cancer. 2015; 15:92. 
62. Long JD, Sullivan TB, Humphrey J, Logvinenko T, Summerhayes KA, Kozinn S, Harty N, Summerhayes IC, Libertino JA, Holway AH, Rieger-Christ KM. A noninvasive miRNA based assay to detect bladder cancer in cell-free urine. American journal of translational research. 2015; 7:2500-2509.

63. Wang J, Zhang X, Wang L, Dong Z, Du L, Yang Y, Guo Y, Wang C. Downregulation of urinary cell-free microRNA-214 as a diagnostic and prognostic biomarker in bladder cancer. Journal of surgical oncology. 2015; 111:992-999.

64. Sapre N, Macintyre G, Clarkson M, Naeem H, Cmero M, Kowalczyk A, Anderson PD, Costello AJ, Corcoran NM, Hovens CM. A urinary microRNA signature can predict the presence of bladder urothelial carcinoma in patients undergoing surveillance. Br J Cancer. 2016; 114:454-462.

65. Pospisilova S, Pazourkova E, Horinek A, Brisuda A, Svobodova I, Soukup V, Hrbacek J, Capoun O, Hanus T, Mares J, Korabecna M, Babjuk M. MicroRNAs in urine supernatant as potential non-invasive markers for bladder cancer detection. Neoplasma. 2016; 63:799-808.

66. Urquidi V, Netherton M, Gomes-Giacoia E, Serie DJ, Eckel-Passow J, Rosser CJ, Goodison S. A microRNA biomarker panel for the non-invasive detection of bladder cancer. Oncotarget. 2016; 7:86290-86299. doi: 10.18632/ oncotarget.13382.

67. Roos PH, Jakubowski N. Methods for the discovery of low-abundance biomarkers for urinary bladder cancer in biological fluids. Bioanalysis. 2010; 2:295-309.

68. Jiang X, Du L, Wang L, Li J, Liu Y, Zheng G, Qu A, Zhang $X$, Pan H, Yang Y, Wang C. Serum microRNA expression signatures identified from genome-wide microRNA profiling serve as novel noninvasive biomarkers for diagnosis and recurrence of bladder cancer. Int J Cancer. 2015; 136:854-862.

69. Du M, Shi D, Yuan L, Li P, Chu H, Qin C, Yin C, Zhang Z, Wang M. Circulating miR-497 and miR-663b in plasma are potential novel biomarkers for bladder cancer. Sci Rep. 2015; 5:10437.

70. Bossuyt PM, Reitsma JB, Bruns DE, Gatsonis CA, Glasziou PP, Irwig LM, Lijmer JG, Moher D, Rennie D, de Vet HC. Towards complete and accurate reporting of studies of diagnostic accuracy: the STARD initiative. Standards for Reporting of Diagnostic Accuracy. Clinical chemistry. 2003; 49:1-6.

71. Kirschner MB, Edelman JJ, Kao SC, Vallely MP, van Zandwijk N, Reid G. The Impact of Hemolysis on Cell-Free microRNA Biomarkers. Frontiers in genetics. 2013; 4:94.

72. MacLellan SA, MacAulay C, Lam S, Garnis C. Preprofiling factors influencing serum microRNA levels. BMC clinical pathology. 2014; 14:27.

73. Scheffer AR, Holdenrieder S, Kristiansen G, von Ruecker A, Muller SC, Ellinger J. Circulating microRNAs in serum: novel biomarkers for patients with bladder cancer? World J
Urol. 2014; 32:353-358.

74. Kriebel S, Schmidt D, Holdenrieder S, Goltz D, Kristiansen G, Moritz R, Fisang C, Muller SC, Ellinger J. Analysis of tissue and serum microRNA expression in patients with upper urinary tract urothelial cancer. PLoS One. 2015; 10:e0117284.

75. Adam L, Wszolek MF, Liu CG, Jing W, Diao L, Zien A, Zhang JD, Jackson D, Dinney CP. Plasma microRNA profiles for bladder cancer detection. Urologic oncology. 2013; 31:1701-1708.

76. Feng Y, Liu J, Kang Y, He Y, Liang B, Yang P, Yu Z. miR$19 \mathrm{a}$ acts as an oncogenic microRNA and is up-regulated in bladder cancer. Journal of experimental \& clinical cancer research. 2014; 33:67.

77. Armstrong DA, Green BB, Seigne JD, Schned AR, Marsit CJ. MicroRNA molecular profiling from matched tumor and bio-fluids in bladder cancer. Molecular cancer. 2015; 14:194.

78. Motawi TK, Rizk SM, Ibrahim TM, Ibrahim IA. Circulating microRNAs, miR-92a, miR-100 and miR-143, as noninvasive biomarkers for bladder cancer diagnosis. Cell biochemistry and function. 2016; 34:142-148.

79. Yang Y, Qu A, Liu J, Wang R, Liu Y, Li G, Duan W, Fang Q, Jiang X, Wang L, Zheng G, Du L, Zhang X, Wang C. Serum miR-210 Contributes to Tumor Detection, Stage Prediction and Dynamic Surveillance in Patients with Bladder Cancer. PLoS One. 2015; 10:e0135168.

80. Feng Y, Kang Y, He Y, Liu J, Liang B, Yang P, Yu Z. microRNA-99a acts as a tumor suppressor and is downregulated in bladder cancer. BMC urology. 2014; 14:50.

81. Tao J, Yang X, Li P, Wei J, Deng X, Cheng Y, Qin C, Ju X, Meng X, Li J, Gu M, Lu Q, Yin C. Identification of circulating microRNA signatures for upper tract urothelial carcinoma detection. Molecular medicine reports. 2015; 12:6752-6760.

82. de Planell-Saguer M, Rodicio MC. Analytical aspects of microRNA in diagnostics: a review. Anal Chim Acta. 2011; 699:134-152.

83. Ach RA, Wang H, Curry B. Measuring microRNAs: comparisons of microarray and quantitative PCR measurements, and of different total RNA prep methods. BMC biotechnology. 2008; 8:69.

84. Sarver AL. Toward understanding the informatics and statistical aspects of micro-RNA profiling. Journal of cardiovascular translational research. 2010; 3:204-211.

85. Cissell KA, Deo SK. Trends in microRNA detection. Analytical and bioanalytical chemistry. 2009; 394:11091116.

86. Valoczi A, Hornyik C, Varga N, Burgyan J, Kauppinen S, Havelda Z. Sensitive and specific detection of microRNAs by northern blot analysis using LNA-modified oligonucleotide probes. Nucleic Acids Res. 2004; 32:e175.

87. Pall GS, Codony-Servat C, Byrne J, Ritchie L, Hamilton A. Carbodiimide-mediated cross-linking of RNA to nylon 
membranes improves the detection of siRNA, miRNA and piRNA by northern blot. Nucleic Acids Res. 2007; 35:e60.

88. Varallyay E, Burgyan J, Havelda Z. MicroRNA detection by northern blotting using locked nucleic acid probes. Nat Protoc. 2008; 3:190-196.

89. Chamnongpol S, Maroney PA,Nilsen TW. A rapid, quantitative assay for direct detection of microRNAs and other small RNAs using splinted ligation. Methods in molecular biology (Clifton, NJ). 2010; 667:3-17.

90. Cissell KA, Rahimi Y, Shrestha S, Hunt EA, Deo SK. Bioluminescence-based detection of microRNA, miR21 in breast cancer cells. Analytical chemistry. 2008; 80:23192325.

91. Chen C, Ridzon DA, Broomer AJ, Zhou Z, Lee DH, Nguyen JT, Barbisin M, Xu NL, Mahuvakar VR, Andersen MR, Lao KQ, Livak KJ, Guegler KJ. Real-time quantification of microRNAs by stem-loop RT-PCR. Nucleic Acids Res. 2005; 33:e179.

92. Weaver S, Dube S, Mir A, Qin J, Sun G, Ramakrishnan R, Jones RC, Livak KJ. Taking qPCR to a higher level: Analysis of CNV reveals the power of high throughput qPCR to enhance quantitative resolution. Methods (San Diego, Calif). 2010; 50:271-276.

93. Raymond CK, Roberts BS, Garrett-Engele P, Lim LP, Johnson JM. Simple, quantitative primer-extension PCR assay for direct monitoring of microRNAs and shortinterfering RNAs. RNA (New York, NY). 2005; 11:17371744.

94. Neely LA, Patel S, Garver J, Gallo M, Hackett M, McLaughlin S, Nadel M, Harris J, Gullans S, Rooke J. A single-molecule method for the quantitation of microRNA gene expression. Nature methods. 2006; 3:41-46.

95. Kloosterman WP, Wienholds E, de Bruijn E, Kauppinen
S,Plasterk RH. In situ detection of miRNAs in animal embryos using LNA-modified oligonucleotide probes. Nature methods. 2006; 3:27-29.

96. de Planell-Saguer M, Rodicio MC, Mourelatos Z. Rapid in situ codetection of noncoding RNAs and proteins in cells and formalin-fixed paraffin-embedded tissue sections without protease treatment. Nat Protoc. 2010; 5:1061-1073.

97. Obernosterer G, Martinez J, Alenius M. Locked nucleic acid-based in situ detection of microRNAs in mouse tissue sections. Nat Protoc. 2007; 2:1508-1514.

98. Beier M, Boisguerin V. Microfluidic primer extension assay. Methods in molecular biology (Clifton, NJ). 2012; 822:143-152.

99. Li W, Ruan K. MicroRNA detection by microarray. Analytical and bioanalytical chemistry. 2009; 394:11171124.

100. Nelson PT, Baldwin DA, Scearce LM, Oberholtzer JC, Tobias JW, Mourelatos Z. Microarray-based, highthroughput gene expression profiling of microRNAs. Nature methods. 2004; 1:155-161.

101. Takada S, Mano H. Profiling of microRNA expression by mRAP. Nat Protoc. 2007; 2:3136-3145.

102. Volinia S, Calin GA, Liu CG, Ambs S, Cimmino A, Petrocca F, Visone R, Iorio M, Roldo C, Ferracin M, Prueitt RL, Yanaihara N, Lanza G, et al. A microRNA expression signature of human solid tumors defines cancer gene targets. Proc Natl Acad Sci U S A. 2006; 103:2257-2261.

103. Mestdagh P, Hartmann N, Baeriswyl L, Andreasen D, Bernard N, Chen C, Cheo D, D'Andrade P, DeMayo M, Dennis L, Derveaux S, Feng Y, Fulmer-Smentek S, et al. Evaluation of quantitative miRNA expression platforms in the microRNA quality control (miRQC) study. Nature methods. 2014; 11:809-815. 